\title{
Effects of Recycled Fiber Fines on Hand Sheet Properties of Different Unbeaten and Beaten Pulps
}

\section{Utjecaj finih recikliranih vlakana na svojstva ručno izrađenog papira od nemljevene i mljevene celuloze}

\author{
Original scientific paper • Izvorni znanstveni rad \\ Received-prispjelo: 4. 2. 2019. \\ Accepted-prihvaćeno: 15. 7. 2020. \\ UDK: $630 * 862.3 ; 630 * 862.42$ \\ https://doi.org/10.5552/drvind.2020.1904
}

(C) 2020 by the author(s). Licensee Faculty of Forestry, University of Zagreb. This article is an open access article distributed under the terms and conditions of the Creative Commons Attribution (CC BY 4.0) license.

\begin{abstract}
In this study, 5, 10, and $15 \%$ secondary fines of recycled pulp were added to unbeaten and beaten (28 ${ }^{\circ}$ SR) samples of recycled pulp, Turkish Calabrian pine (Pinus brutia Ten.) kraft pulp, and European aspen (Populus tremula L.) kraft pulp. The effects of the addition of fiber fines on hand sheets properties were evaluated. The addition of fiber fines to the unbeaten pulps improved the strength properties of hand sheets. The roughness of hand sheets was also decreased with the addition of fines. When fiber fines were added to the beaten pulps, the type of pulp strongly affected the paper strength properties. The strength properties of beaten pulps of Turkish Calabrian pine and European aspen were decreased with the addition of fiber fines, while the strength properties of beaten pulps of recycled pulp were increased. On the other hand, the air permeance of unbeaten and beaten samples was decreased with the addition of fiber fines. Consequently, the addition of fines to unbeaten and beaten pulps had a more pronounced effect on European aspen kraft pulp and recycled pulp than on Turkish Calabrian pine kraft pulp. Also, the strength of paper made of unbeaten recycled pulp with the addition of $15 \%$ fines was higher than that of fines-free beaten recycled pulp.
\end{abstract}

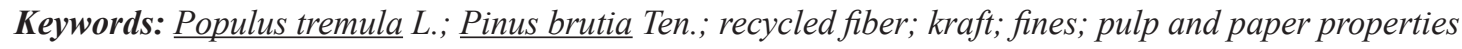

SAŽETAK • U radu je opisano istraživanje u kojemu je mljevenoj i nemljevenoj (28 $\left.{ }^{\circ} \mathrm{SR}\right)$ recikliranoj celulozi, kraft celulozi od brucijskog bora (Pinus brutia Ten.) i kraf celulozi od jasike (Populus tremula L.) dodano 5, $10 i$ $15 \%$ sekundarnih finih vlakana reciklirane celuloze. Utvrđeni su učinci dodavanja finih vlakana na svojstva ručno izrađenih papira. Dodatak vlakana nemljevenoj celulozi pridonio je povećanju čvrstoće i smanjenju hrapavosti ručno izrađenih papira. Pri dodavanju vlakana mljevenoj celulozi velik je utjecaj na čvrstoću papira imala vrsta celuloze. Čvrstoća mljevene celuloze od brucijskog bora i jasike dodatkom vlakana se smanjila, dok se čvrstoća mljevene reciklirane celuloze povećala. Usto, dodatkom vlakana smanjena je propusnost zraka mljevenih $i$ nemljevenih uzoraka. Posljedično, učinak dodavanja vlakana mljevenoj i nemljevenoj celulozi bio je veći za kraft celulozu od jasike i recikliranu celulozu nego za kraft celulozu od brucijskog bora. Također, čvrstoća papira od mljevene reciklirane celuloze s dodatkom $15 \%$ vlakana bila je veća od čvrstoće papira od mljevene celuloze bez dodatka vlakana.

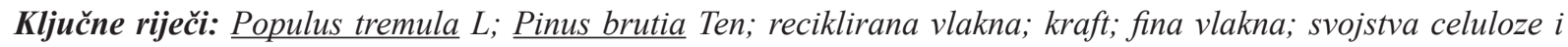
papira

${ }^{1}$ Authors are researchers at Bartin University, Forestry Faculty, Department of Forest Industry Engineering, Bartin, Turkey. 


\section{INTRODUCTION}

\section{UVOD}

The fines are defined as the cellulosic fiber fraction of a fiber suspension which can pass through a 200 mesh (200 wires per inch) screen with a $14.5 \%$ open area and $76.2 \mu \mathrm{m}$ diameter in Bauer McNett classifier (Meyers and Nanko, 2005). Therefore, the fines are sometimes named the P200 (Taipale, 2010). Also, the maximum and minimum fine length is detected as 0.2 $\mathrm{mm}$ and $0.072 \mathrm{~mm}$, respectively (Meyers and Nanko, 2005). On the other hand, fines are extensively evaluated as all particles smaller than wood fibers present in the furnish (Krogerus et al., 2002a). In accordance with this definition, fines may consist of various particles such as parts of wood cells, inorganic pigments and fillers, colloidal resins and latex, salt crystals, precipitates, deposits, etc. (Taipale, 2010).

Fines are generally categorized as primary and secondary fines. Primary fines are present in the pulp prior to refining, whereas secondary fines arise during refining. Primary fines consist mainly of ray cells, parenchyma cells and middle lamella lignin. (Bäckström et al., 2008). Primary or secondary layers of cell wall are delaminated during refining, and they became detached from the fibers. So-formed secondary fines incline to be slender and flexible (Chen et al., 2009).

Primary and secondary fines contribute differently to the mechanical properties of paper (Htun and de Ruvo, 1978). For a given fines content, the effect of secondary fines on strength properties of the pulp are more pronounced than those of primary fines (Hawes and Doshi, 1986; Bäckström et al., 2008). Primary fines have a higher lignin content than kraft pulp fibers (Retulainen et al., 2002). Secondary fines come mostly from the fiber surface during refining, and they have a higher lignin content compared to the fibers, but lower compared to the primary fines (Lindström and Nordmark, 1978). Secondary fines have about twice as much fibrils as primary fines (Krogerus et al., 2002b). In chemical pulp, the cellulose and hemicellulose content of fines is higher than in the fiber fraction (Taipale, 2010). Also, the crystallinity of fines was lower compared to the long fiber fraction (Waterhouse and Omori, 1993).

The term fines is extensively used in the papermaking process, and fines have a significant influence on the behavior of the wet web and on all the properties of the final sheet (Bäckström et al., 2008). Fines can help to fill in the voids between fibers in the paper structure. Fibrillar fines can bring fibers into closer contact with each other during the consolidation and drying of sheet (Johansson, 2008). In other words, fines increase inter-fiber bonding by acting as a bridge between fibers (Bäckström et al., 2008; Retulainen et al., 2002; Silveira et al., 1996). If there are more bonds, the segments between bonds are shorter and there are fewer free loops (Retulainen et al., 1993). Thus, a denser, stronger, and more uniform product is formed (Lin et al., 2007). On the other hand, high levels of fines can make it more difficult to dewater the wet sheet (Liu et al., 2001; Krogerus et al., 2002b; Seth,
2003; Hubbe and Heitmann, 2007). The difficulty in dewatering produces a deceleration in the manufacturing process (Htun and de Ruvo, 1978; Taipale, 2010), causing an increase in the amount of energy required to dry the paper (Chen et al., 2009).

The effect of fines on paper properties of mechanical pulps (Mohlin, 1977; Moss and Retulainen, 1997; Lu, 1999; Luukko and Paulapuro, 1999; Rundlöf, 2002; Vainio et al., 2007; Asikainen et al., 2010; Chen et al., 2013; Moberg et al., 2014) and chemical pulps (Kibblewhite,1972; Lobben, 1977; Htun and de Ruvo, 1978; Hartman, 1984; Przybysz and Czechowski, 1985; Retulainen et al., 1993, 2002; Retulainen, 1997; Ferreira et al., 2000; Krogerus et al., 2002a; Taipale et $a l ., 2010$ ) have been extensively studied. However, the influences of the addition of fines on the paper properties of the recycled pulps have seldom been reported. In general, fines (primary and secondary fines) of the recycled pulps are considered as undesirable for the strength properties, because the fines are produced from dried and hornified fibers. Mancebo and Krokoska (1985) noted that the fines of recycled pulp have a negative impact on paper strength as they act as filler material. The fines indicate the loss of bonding ability due to hornification, and it is claimed that the effect is irreversible even with refining. Also, Szwarcsztajn and Przybysz (1977) found that fines and fibers obtained from recycled paper hornified, causing the loss of the paper strength. Quite the contrary, Hawes and Doshi (1986) noted that fines of recycled paper are effective in increasing the strength of hand sheets made from recycled paper. The recycled fines act like virgin fines, so the removal of fines causes a reduction in the bonding index (Htun and de Ruvo, 1978; Klungness and Sanyer, 1981; Rushdan, 2005). Recently, the effect of fine content and quality on the recycled chemical pulps was studied by Lee et al., (2011).

In this study, the effects of the addition of secondary fines to recycled pulp $(5,10$, and $15 \%)$ on hand sheet properties were evaluated. Three types of pulp were used, recycled pulp, Turkish Calabrian pine ( $P i$ nus brutia Ten.) kraft pulp, and European aspen (Populus tremula L.) kraft pulp, in order to determine the relationship between the addition of fines and the type of pulp. Also, two types of freeness level were used, unbeaten pulp and $28{ }^{\circ} \mathrm{SR}$ pulp, in order to investigate the effect of fines on pulps at different freeness levels.

\section{MATERIALS AND METHODS} 2. MATERIJALI I METODE

Unbleached recycled pulps used in this study were obtained from Oyka pulp mill in Turkey. Turkish Calabrian pine and European aspen wood samples were obtained from Bartin province of Turkey. The wood samples were debarked and chipped to $3 \mathrm{~cm} \times 1.5 \mathrm{~cm} \times$ $0.5 \mathrm{~cm}$ size for kraft pulping. The air dried wood chips were stored in dry conditions. The kraft cooking conditions of both species are given in Table 1 .

Cooking was carried out in a $15-\mathrm{L}$ electrically heated laboratory cylindrical-type rotary digester. After 
..... Gülsoy, Uysal: Effects of Recycled Fiber Fines on Hand Sheet Properties of Different...

Table 1 Kraft cooking conditions of both species

Tablica 1. Uvjeti kuhanja kraft celuloze od obje vrste drva

\begin{tabular}{|l|c|c|c|c|c|c|}
\hline \multicolumn{1}{|c|}{$\begin{array}{c}\text { Tree species } \\
\text { Vrste drva }\end{array}$} & $\begin{array}{c}\text { Active } \\
\text { alkali } \\
\text { Aktivna } \\
\text { lužina } \\
\%\end{array}$ & $\begin{array}{c}\text { Sulfidity } \\
\text { Sulfidnost } \\
\%\end{array}$ & $\begin{array}{c}\text { Cooking } \\
\text { temp } \\
\text { Temperatura } \\
\text { kuhanja, } \\
{ }^{\circ} \mathrm{C}\end{array}$ & $\begin{array}{c}\text { Cooking time to } \\
\text { max. temp } \\
\text { Vrijeme kuhanja do } \\
\text { najviše temperature } \\
\text { min }\end{array}$ & $\begin{array}{c}\text { Cooking time at } \\
\text { max. temp } \\
\text { Vrijeme kuhanja na } \\
\text { najvišoj temperaturi } \\
\text { min }\end{array}$ & $\begin{array}{c}\text { Liquor/ } \\
\text { wood ratio } \\
\text { Omjer } \\
\text { otapalo/ } \\
\text { drvo }\end{array}$ \\
\hline $\begin{array}{l}\text { Turkish Calabrian pine } \\
\text { brucijski bor }\end{array}$ & 18 & 25 & 170 & 90 & 75 & $4 / 1$ \\
\hline European aspen / jasika & 16 & 20 & 170 & 90 & 60 & $4 / 1$ \\
\hline
\end{tabular}

digestion, pulps were washed to remove black liquor and were disintegrated in a laboratory-type pulp mixer. Disintegrated pulps were screened using a Somervilletype pulp screen with $0.15-\mathrm{mm}$ slotted plate (TAPPI T 275). Pulps were then beaten to $28^{\circ} \mathrm{SR}$ in a Valley Beater according to TAPPI T 200. Kappa number (TAPPI T 236), screened yield (TAPPI T 210), viscosity (SCANCM 15-62), and freeness of pulps (ISO 5267-1) were determined according to relevant methods.

The secondary fines were acquired by refining the recycled pulps in a Valley beater for $7 \mathrm{~h}$ with loading according to TAPPI $\mathrm{T} 200$. The refined pulp was fractionated in a Bauer-McNett classifier (TAPPI T 233) into five fractions: R30, R50, R100, R200, and R300 mesh. Fines passing through a 200 mesh screen and retained by a 300 mesh were used as paper additive. The fiber morphology of the different pulps and secondary fines was determined with light microscope. Some pulp properties and fiber morphology of different pulps and fines are given in Table 2.
Different mixtures of unbeaten and beaten pulps of different fibers (Turkish Calabrian pine, European aspen, and recycled fiber) and secondary fines were used to prepare hand sheets and to determine the effect of fines on paper strength properties. Four levels of fines were used: $0,5,10$, and $15 \%$ of the dry weight of the fibers (Table 3). More than $15 \%$ fines were not used due to difficulty in dewatering and drainage during papermaking. Freeness of fines added pulps (ISO 5267-1) was also determined. The hand sheets (70 g/ $\mathrm{m}^{2}$ ) made by a Rapid-Kothen Sheet Former (ISO 52692) were conditioned (TAPPI T 402). Tensile index (ISO 1924-3), burst index (TAPPI T 403), tear index (TAPPI $\mathrm{T}$ 414), roughness (ISO 8791-2), apparent density (TAPPI T 220), and air permeance (ISO 5636-3) of the hand sheets were also determined.

The data of hand sheet properties were subjected to analysis of variance (ANOVAs) and Duncan test at a 0.05 probability level. The same lower case letter in all figures denotes that the difference in the average values

Table 2 Some pulp properties and fiber morphology of different pulps and fines

Tablica 2. Svojstva celuloze i morfologija vlakana od različitih vrsta celuloze i finih vlakana

\begin{tabular}{|l|c|c|c|c|c|c|}
\hline \multicolumn{1}{|c|}{ Sample / Uzorak } & $\begin{array}{c}\text { Viscosity } \\
\text { Viskoznost } \\
\mathrm{cm}^{3} / \mathrm{g}\end{array}$ & $\begin{array}{c}\text { Kappa } \\
\text { number } \\
\text { Kappa } \\
\text { broj }\end{array}$ & $\begin{array}{c}\text { Fiber } \\
\text { lengthmm } \\
\text { Duljina } \\
\text { vlakana } \\
\mathrm{mm}\end{array}$ & $\begin{array}{c}\text { Fiber width } \\
\text { Sirina } \\
\text { vlakana } \\
\mu \mathrm{m}\end{array}$ & $\begin{array}{c}\text { Lumen } \\
\text { width } \\
\text { Sirina } \\
\text { lumena } \\
\mu \mathrm{m}\end{array}$ & $\begin{array}{c}\text { Cell wall } \\
\text { thickness } \\
\text { Debljina } \\
\text { stanične stijenke } \\
\mu \mathrm{m}\end{array}$ \\
\hline $\begin{array}{l}\text { Turkish Calabrian pine kraft pulp } \\
\text { kraft celuloza od brucijskog bora }\end{array}$ & 888 & 31.4 & 2.90 & 54.50 & 28.50 & 13.00 \\
\hline $\begin{array}{l}\text { European aspen kraft pulp } \\
\text { kraft celuloza od jasike }\end{array}$ & 1121 & 32.5 & 1.18 & 24.25 & 10.50 & 6.88 \\
\hline Recycled pulp / reciklirana celuloza & 580 & 31.2 & 1.66 & 28.00 & 10.75 & 8.63 \\
\hline Fines / fina vlakna & - & - & 0.21 & 23.50 & 11.00 & 6.25 \\
\hline
\end{tabular}

Table 3 Fiber and fines mixing ratios used in this study

Tablica 3. Omjer vlakana i finih vlakana u smjesi rabljenoj u ovom istraživanju

\begin{tabular}{|c|l|}
\hline $\begin{array}{c}\text { Code } \\
\text { Oznaka }\end{array}$ & Mixing ratio / Omjer miješanja \\
\hline A0 & $100 \%$ Turkish Calabrian pine kraft pulp / $100 \%$ kraft celuloze od brucijskog bora \\
\hline A5 & $95 \%$ Turkish Calabrian pine kraft pulp $+5 \%$ fines / $95 \%$ kraft celuloze od brucijskog bora $+5 \%$ finih vlakana \\
\hline A10 & $90 \%$ Turkish Calabrian pine kraft pulp $+10 \%$ fines / $90 \%$ kraft celuloze od brucijskog bora $+10 \%$ finih vlakana \\
\hline A15 & $85 \%$ Turkish Calabrian pine kraft pulp $+15 \%$ fines / $85 \%$ kraft celuloze od brucijskog bora $+15 \%$ finih vlakana \\
\hline B0 & $100 \%$ European aspen kraft pulp / $100 \%$ kraft celuloze od jasike \\
\hline B5 & $95 \%$ European aspen kraft pulp $+5 \%$ fines / $95 \%$ kraft celuloze od jasike $+5 \%$ finih vlakana \\
\hline B10 & $90 \%$ European aspen kraft pulp $+10 \%$ fines / $90 \%$ kraft celuloze od jasike $+10 \%$ finih vlakana \\
\hline B15 & $85 \%$ European aspen kraft pulp $+15 \%$ fines / $85 \%$ kraft celuloze od jasike $+15 \%$ finih vlakana \\
\hline C0 & $100 \%$ recycled pulp / $100 \%$ reciklirane celuloze \\
\hline C5 & $95 \%$ recycled pulp $+5 \%$ fines / $95 \%$ reciklirane celuloze $+5 \%$ finih vlakana \\
\hline C10 & $90 \%$ recycled pulp $+10 \%$ fines / $90 \%$ reciklirane celuloze $+10 \%$ finih vlakana \\
\hline C15 & $85 \%$ recycled pulp $+15 \%$ fines / $85 \%$ reciklirane celuloze $+15 \%$ finih vlakana \\
\hline
\end{tabular}


of properties among the compared groups was statistically insignificant.

\section{RESULTS AND DISCUSSION} 3. REZULTATI I RASPRAVA

\subsection{Pulp freeness}

3.1. Sposobnost odvodnjavanja celuloze

Drainage, an important parameter in the paper manufacturing, restricts the production efficiency of a paper machine (Norell et al., 1999). Important factors influencing wetness end drainage are pulp composition, average fiber length, fiber length distribution, fines content, charge level on the stock, and degree of stock hydration (Paradis et al., 2002). Fines have a detrimental effect on dewatering of the pulp suspension due to their high water holding capacity (Htun and de Ruvo, 1978; Hartman, 1984; Waterhouse and Omiri 1993; Liu et al., 2001; Hubbe and Heitmann 2007; Chen et al., 2009; Taipale et al., 2010; Lee et al., 2011; Lindqvist et al., 2011). Lu (1999) noted that the pulp containing $40 \%$ of fines drains 10 times more slowly than fines-free pulp. Kibblewhite (1972) reported that the pulp freeness strongly affected the quality and quantity of fines. Seth (2003) noted that pulp freeness drastically decreases with the addition of fines. The effect of the addition of fines on pulp freeness of unbeaten and beaten pulps is given in Table 4 . The pulp freeness was decreased with increasing fines ratio.

\subsection{Tensile index}

\subsection{Vlačni indeks}

Tensile index is one of the basic strength properties of paper. The effect of the addition of fines on tensile index of the unbeaten and beaten pulps was more pronounced in European aspen kraft pulp and recycled pulp than in Turkish Calabrian pine kraft pulp (Figure 1). On the other hand, the effect of the addition of fines on tensile index of unbeaten pulps was more prominent than of beaten pulps. The effect was more pronounced at a higher level of addition. Lobben (1977) reported

Table 4 The effect of fines addition on pulp freeness of unbeaten and beaten pulps

Tablica 4. Utjecaj dodatka finih vlakana na sposobnost odvodnjavanja mljevene i nemljevene celuloze

\begin{tabular}{|c|c|c|}
\hline $\begin{array}{c}\text { Code } \\
\text { Oznaka }\end{array}$ & $\begin{array}{c}\text { Unbeaten pulp } \\
\text { Nemljevena celuloza } \\
{ }^{\text {oSR }}\end{array}$ & $\begin{array}{c}\text { Beaten pulp } \\
\text { Mljevena celuloza } \\
{ }^{\text {'SR }}\end{array}$ \\
\hline A0 & 13 & 28 \\
\hline A5 & 15 & 41 \\
\hline A10 & 16 & 50 \\
\hline A15 & 27 & 59 \\
\hline B0 & 13 & 28 \\
\hline B5 & 17 & 38 \\
\hline B10 & 22 & 45 \\
\hline B15 & 28 & 51 \\
\hline C0 & 20 & 28 \\
\hline C5 & 25 & 35 \\
\hline C10 & 34 & 43 \\
\hline C15 & 37 & 55 \\
\hline
\end{tabular}

that the fines of chemical pulps had a considerable effect on strength properties depending on fiber type and freeness level of pulp. The effect of the addition of fines was greater for a eucalypt kraft pulp than for a pine kraft pulp. Also, the effects were more pronounced in unbeaten pulps of long fiber fraction.

As can be seen in Figure 1, the addition of 5, 10, and $15 \%$ secondary fines to Turkish Calabrian pine unbeaten kraft pulps resulted in the increase in tensile index of $13.14 \%, 20.22 \%$, and $29.68 \%$, respectively $(p<0.05)$. The addition of 5,10 , and $15 \%$ secondary fines to unbeaten European aspen kraft pulp resulted in the increase in tensile index of $55.22 \%, 60.49 \%$, and $85.07 \%$, respectively. The addition of 5,10 , and $15 \%$ secondary fines to recycled unbeaten pulps resulted in the increase in tensile index of $16.29 \%, 36.80 \%$, and $43.49 \%$, respectively $(p<0.05)$. Tensile index did not deteriorate with increasing addition of fines, and the more fines in hand sheet caused better bonding. These findings can be attributed to the increase in fiber-fiber bonding area due to the filling of inter-fiber gaps in the paper structure by fines. On the other hand, the addition of fines to fiber suspension results in the decreased average fiber length. However, tensile index of hand sheets did not decrease. This may be due to increasing fiber-fiber bonding thanks to the presence of fines, which overcompensated for the impaired tensile index caused by the decreasing average fiber length.

Previous studies revealed that the recycled fines act like virgin fines, causing an increase in the bonding index (Hawes and Doshi, 1986; Htun and de Ruvo, 1978; Klungness and Sanyer, 1981; Rushdan, 2005). In this study, the recycled fines did not act as a filler as found in other studies (Szwarcsztajn and Przybysz, 1977; Manchebo and Krokoska, 1985). Asikainen et al., (2010) noted that tensile index increased with the addition of $10 \%$ and $20 \%$ primary fines to CTMP from $22.5 \mathrm{Nm} / \mathrm{g}$ to $26.8 \mathrm{Nm} / \mathrm{g}$ and $31.0 \mathrm{Nm} / \mathrm{g}$, respectively. Retulainen (1997) reported that, by adding $3 \%$ kraft fines to a kraft long fiber fraction, the tensile strength increases by $18 \%$. On the other hand, Lindqvist et al., (2011) and Ferreira et al., (2000) noted that the removal of fines resulted in decreased tensile index. The positive effect of the addition of fines on tensile index of hand sheets has been reported by several authors (Bäckström et al., 2008; Retulainen, 1997; Mohlin, 1977; Hartman, 1984; Mancebo and Krokoska, 1985; Retulainen et al., 1993; Waterhouse and Omiri, 1993; Waterhouse, 1994; Rundlöf, 2002; Vainio et al., 2007; Taipale et al., 2010; Zaytseva, 2010; Lee et al., 2011).

In the beaten samples of Turkish Calabrian pine and European aspen kraft pulp, the addition of fines had not a statistically significant effect on tensile index of hand sheets $(p>0.05)$ (Figure 1). The tensile index of recycled beaten pulps increased with the addition of 5 , 10 , and $15 \%$ of secondary fines by $10.96 \%, 22.47 \%$, and $34.47 \%$, respectively $(p<0.05)$. These results can be attributed to better response to beating of virgin (flexible) fibers than recycled (stiff) fibers due to differences in their fiber morphology. Tensile index of 


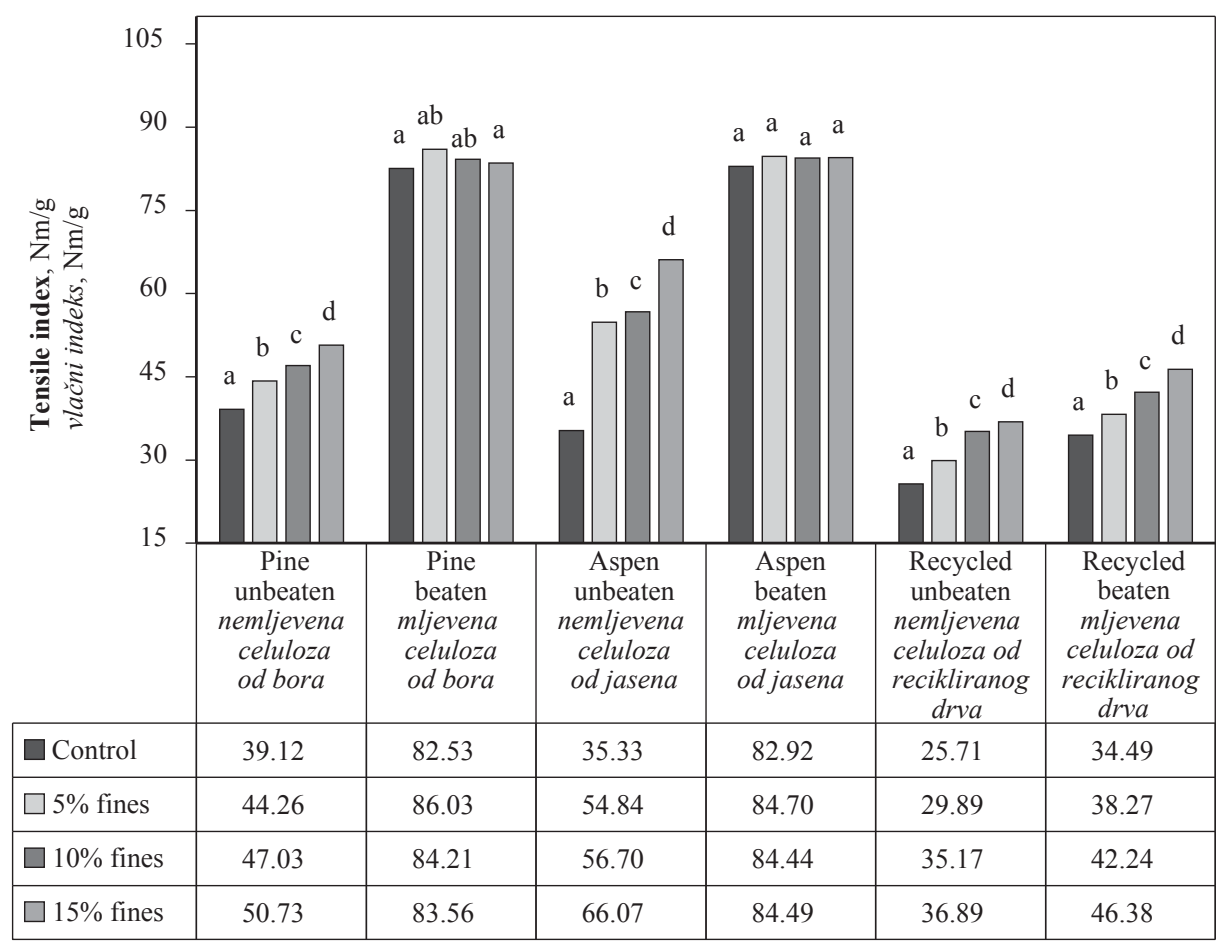

Figure 1 Effect of fines addition on tensile index of hand sheets of unbeaten and beaten pulps

Slika 1. Utjecaj dodatka finih vlakana na vlačni indeks papira od nemljevene i mljevene celuloze

Turkish Calabrian pine and European aspen pulp samples was increased with beating to $28^{\circ} \mathrm{SR}$ by $110.97 \%$ (from $39.12 \mathrm{Nm} / \mathrm{g}$ to $82.53 \mathrm{Nm} / \mathrm{g}$ ) and $134.70 \%$ (from $35.33 \mathrm{Nm} / \mathrm{g}$ to $82.92 \mathrm{Nm} / \mathrm{g}$ ), respectively, while in recycled pulp samples this increase was only $34.15 \%$ (from $25.71 \mathrm{Nm} / \mathrm{g}$ to $34.49 \mathrm{Nm} / \mathrm{g}$ ). The lower tensile index increase in beaten recycled pulp was compensated with the addition of fines (Figure 1). On the other hand, tensile index of unbeaten recycled pulp (36.89 $\mathrm{Nm} / \mathrm{g}$ ), with the addition of $15 \%$ fines, was higher than that of fines-free beaten recycled pulp $(34.49 \mathrm{Nm} / \mathrm{g})$.

\subsection{Tear index}

\subsection{Indeks cijepanja}

The effect of the addition of fines on tear index of hand sheet depends on the type of pulp and the amount of fines added. Tear index of Turkish Calabrian pine unbeaten kraft pulps decreased with the addition of 5 , 10 , and $15 \%$ secondary fines by $11.17 \%, 17.04 \%$, and $27.99 \%$, respectively $(p<0.05)$. Quite the contrary, tear index of European black pine unbeaten kraft pulp and recycled unbeaten pulp increased with the addition of 5,10 , and $15 \%$ secondary fines by $19.25 \%, 22.99 \%$, $25.93 \%$ and $12.40 \%, 17.61 \%, 9.42 \%$, respectively $(p<0.05)$. These results showed that the addition of fines had a positive effect on tear index of hand sheets obtained from short fibers compared to long fibers (Figure 2). This result is consistent with previous work (Hawes and Doshi, 1986), which showed that tear index increased with the addition of $20 \%$ secondary fines to recycled pulp from $8.7 \mathrm{mNm}^{2} / \mathrm{g}$ to 9.95 $\mathrm{mNm}^{2} / \mathrm{g}$. Ferreira et al., (2000) noted that tear index increased from $9.5 \mathrm{mNm}^{2} / \mathrm{g}$ to $10.2 \mathrm{mNm}^{2} / \mathrm{g}$ when fines were removed from fiber suspension. The positive correlation between tear index and fines addition has also been reported by several authors (Mohlin, 1977; Hartman, 1984; Lee et al., 2011). Quite the contrary, tear index decreased with the addition of fines (Waterhouse, 1994).

Tear index of Turkish Calabrian pine unbeaten kraft pulp decreased with the increasing addition of fines, while it increased for European aspen unbeaten kraft pulp and unbeaten recycled pulp (Figure 2). This result may be explained as follows. Tear index depends on several factors, including fiber length, wall thickness, inter-fiber bonding, fiber strength, etc. Fines contribute to tear index by increasing inter-fiber bonding due to their good flexibility and large surface area. Thus, tear index of short fiber European aspen and recycled pulp samples was increased with the addition of fines. As fines content increased, the average fiber length and wall thickness decreased. Also, the larger gaps between long fibers of Turkish Calabrian pine were not sufficiently filled by fines, resulting in lower inter-fiber bonding than samples without fines. Hence, tear index of Turkish Calabrian pine sample was decreased with the addition of fines.

In beaten pulps, tear index of Turkish Calabrian pine and European aspen kraft pulps decreased with the addition of 5,10 , and $15 \%$ secondary fines by $6.37 \%$, $11.67 \%, 11.14 \%$ and $4.15 \%, 10.65 \%, 11.95 \%$, respectively $(p<0.05)$ (Figure 2). Quite the contrary, the addition of 5,10 , and $15 \%$ secondary fines to recycled unbeaten pulp resulted in the increase in tear index of $5.39 \%, 10.56 \%$, and $4.46 \%$, respectively $(p<0.05)$. These results showed that the effect of fines addition on tear index was more prominent than beating. For example, tear index of recycled unbeaten pulp was increased by beating up to $28{ }^{\circ} \mathrm{SR}$ from $4.03 \mathrm{mNm}^{2} / \mathrm{g}$ to 4.26 $\mathrm{mNm}^{2} / \mathrm{g}$. However, with the addition of $15 \%$ fines, tear 


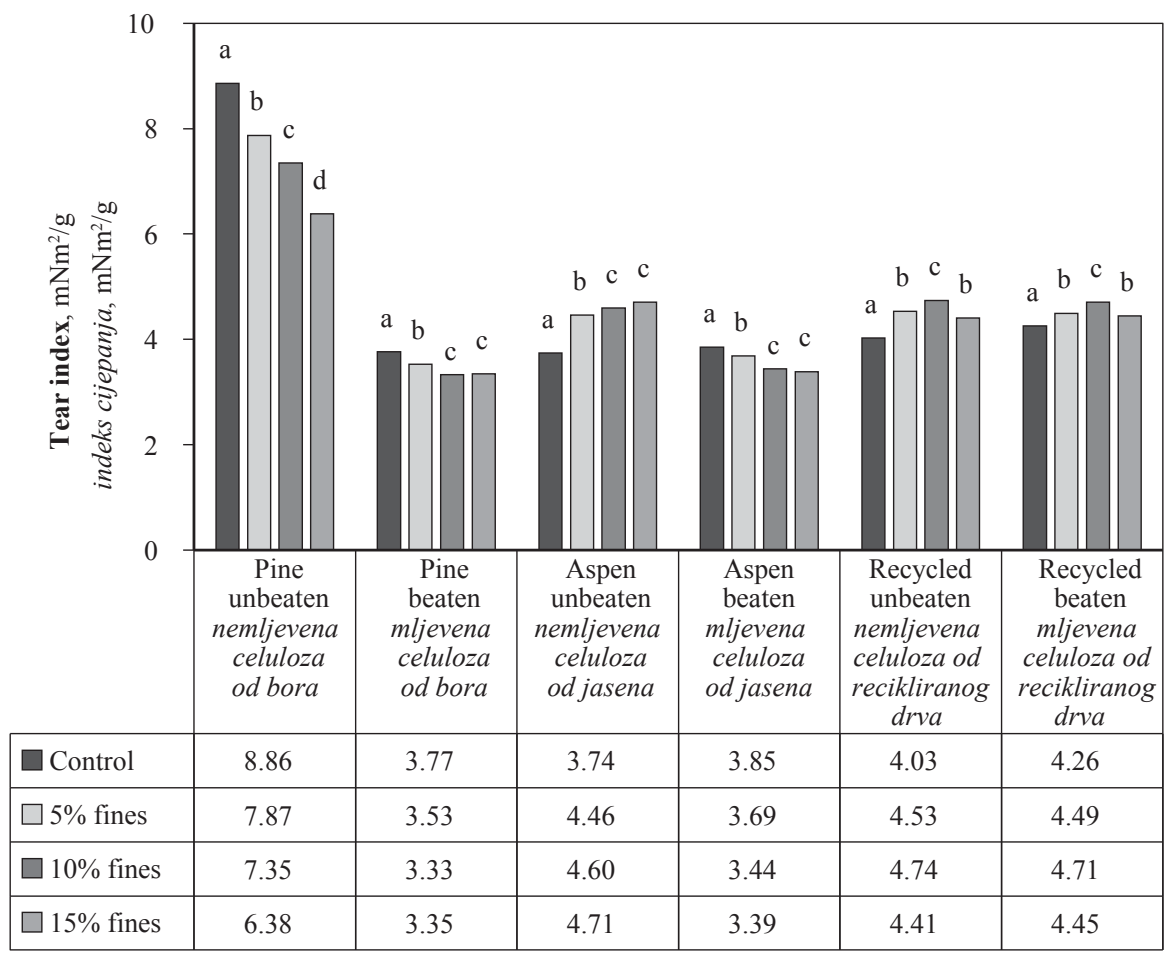

Figure 2 Effect of fines addition on tear index of hand sheets of unbeaten and beaten pulps

Slika 2. Utjecaj dodatka finih vlakana na indeks cijepanja papira od nemljevene i mljevene celuloze

index of recycled unbeaten pulp was increased from $4.03 \mathrm{mNm}^{2} / \mathrm{g}$ to $4.41 \mathrm{mNm}^{2} / \mathrm{g}$. On the other hand, when $15 \%$ fines were added to unbeaten recycled pulp (4.41 $\left.\mathrm{mNm}^{2} / \mathrm{g}\right)$, tear index was higher than that of fines-free beaten recycled pulp $\left(4.26 \mathrm{mNm}^{2} / \mathrm{g}\right)$.

\subsection{Burst index}

3.4. Indeks pucanja

In unbeaten pulps of all types of pulp, the addition of fines caused an increase in burst index (Figure 3 ). The highest increase in burst index was determined in European aspen kraft pulp. The addition of 5, 10, and $15 \%$ secondary fines to Turkish Calabrian pine kraft pulp resulted in the increase in burst index of $14.34 \%, 30.43 \%$, and $42.60 \%$, respectively $(p<0.05)$. The increase of burst index in European aspen kraft pulp and recycled pulp was found to be $26.73 \%, 57.75$ $\%, 67.91 \%$ and $10.48 \%, 33.87 \%, 37.09 \%$, respectively $(p<0.05)$. The burst index of hand sheets increased linearly with increasing proportion of fines (Figure 3). These findings can be ascribed to increasing inter-fiber bonding due to higher surface area of fines than fibers. The surface area of fines ranges from 10 to $50 \mathrm{~m}^{2} / \mathrm{g}$, while the surface area of fibers is around 1 $\mathrm{m}^{2} / \mathrm{g}$ (Retulainen et al., 1993).

Hawes and Doshi (1986) reported that burst index increased with the addition of $20 \%$ secondary fines to recycled pulp from $1.39 \mathrm{kPam}^{2} / \mathrm{g}$ to 3.86 $\mathrm{kPam}^{2} / \mathrm{g}$. Ferreira et al., (2000) noted that burst index decreased from $6.9 \mathrm{kPam}^{2} / \mathrm{g}$ to $5.0 \mathrm{kPam}^{2} / \mathrm{g}$ when fines were removed from fiber suspension. Other authors reported that burst index increases with the addition of fines (Mohlin, 1977; Htun and de Ruvo, 1978; Klungness and Sanyer, 1981; Hawes and Doshi, 1986; Waterhouse, 1994; Bäckström et al., 2008).
In beaten pulps, the addition of 5, 10, and $15 \%$ secondary fines to Turkish Calabrian pine kraft pulp resulted in burst index loss of $1.93 \%, 6.21 \%$, and $3.64 \%$, respectively $(p<0.05)$. Quite the contrary, the addition of secondary fines to European aspen kraft pulp resulted in a statistically insignificant increase of burst index, $(p>0.05)$. On the other hand, an increase in burst index of $12.12 \%, 20 \%$, and $43.03 \%$, respectively $(p<0.05)$, was observed in recycled pulp with the addition of 5, 10, and $15 \%$ secondary fines. In beaten pulps, the relationship between burst index and fines addition is drastically different depending on the type of pulp (Figure 3). These results can be explained by increased inter-fiber bonding that acts as a bridge of fines between hornified and stiff recycled fibers. Thus, the strength of paper made from recycled fibers with low bonding capacity increases with the addition of fines. Along with the beating, the decrease in fiber length and the improved fiber flexibility and plasticity increase the bonded area between fibers. Thus, the paper structure became more compact and burst index increased. Also, the mobility of fines may be lower in the wet sheet of collapsed, swollen, and externally fibrillated fibers compared to the more open structure in a wet sheet of unbeaten fibers (Hartman, 1984).

In the virgin pulp samples, freeness level of pulp had a more significant effect on burst index than the fines content. For example, burst index of Turkish Calabrian pine kraft pulp was increased with beating up to $28{ }^{\circ} \mathrm{SR}$ from $2.30 \mathrm{kPam}^{2} / \mathrm{g}$ to $4.67 \mathrm{kPam}^{2} / \mathrm{g}$. However, burst index of Turkish Calabrian pine unbeaten kraft pulp was increased from $2.30 \mathrm{kPam}^{2} / \mathrm{g}$ to $3.28 \mathrm{kPam}^{2} / \mathrm{g}$ with the addition of $15 \%$ fines. In the recycled pulp sample, the effect of freeness level of pulp and fines addition on burst index was similar. Burst index of recy- 


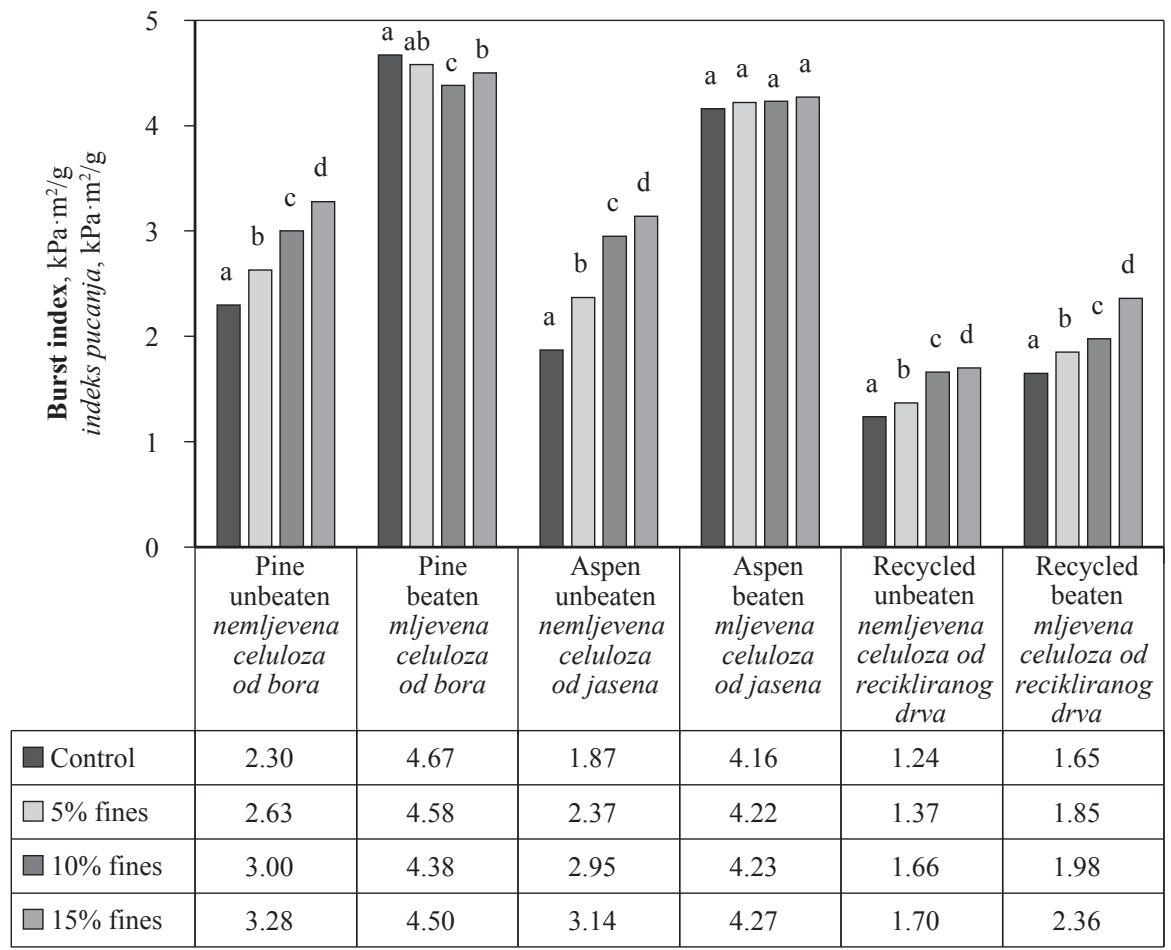

Figure 3 Effect of fines addition on burst index of hand sheets of unbeaten and beaten pulps

Slika 3. Utjecaj dodatka finih vlakana na indeks pucanja papira od nemljevene i mljevene celuloze

cled pulp was increased with beating up to $28^{\circ} \mathrm{SR}$ from $1.24 \mathrm{kPam}^{2} / \mathrm{g}$ to $1.65 \mathrm{kPam}^{2} / \mathrm{g}$. However, burst index of recycled unbeaten pulp was increased from $1.24 \mathrm{kPam}^{2} / \mathrm{g}$ to $1.70 \mathrm{kPam}^{2} / \mathrm{g}$ with the addition of $15 \%$ fines.

\subsection{Apparent density}

\subsection{Prividna gustoća}

As the addition of fines increased, the apparent density of the hand sheets increased linearly as shown in Figure 4. The highest increase in apparent density was determined in Turkish Calabrian pine kraft pulp. The addition of 5, 10, and $15 \%$ secondary fines to Turkish Calabrian pine kraft pulp resulted in an increase in apparent density of $3.51 \%, 7.02 \%$, and $12.28 \%$, respectively $(p<0.05)$. An increase in apparent density of $3.13 \%, 4.68 \%, 7.81 \%$ and $7.55 \%, 7.55 \%, 11.32$ $\%$, respectively $(p<0.05)$, was determined in European aspen kraft pulp and recycled pulp. This is consistent

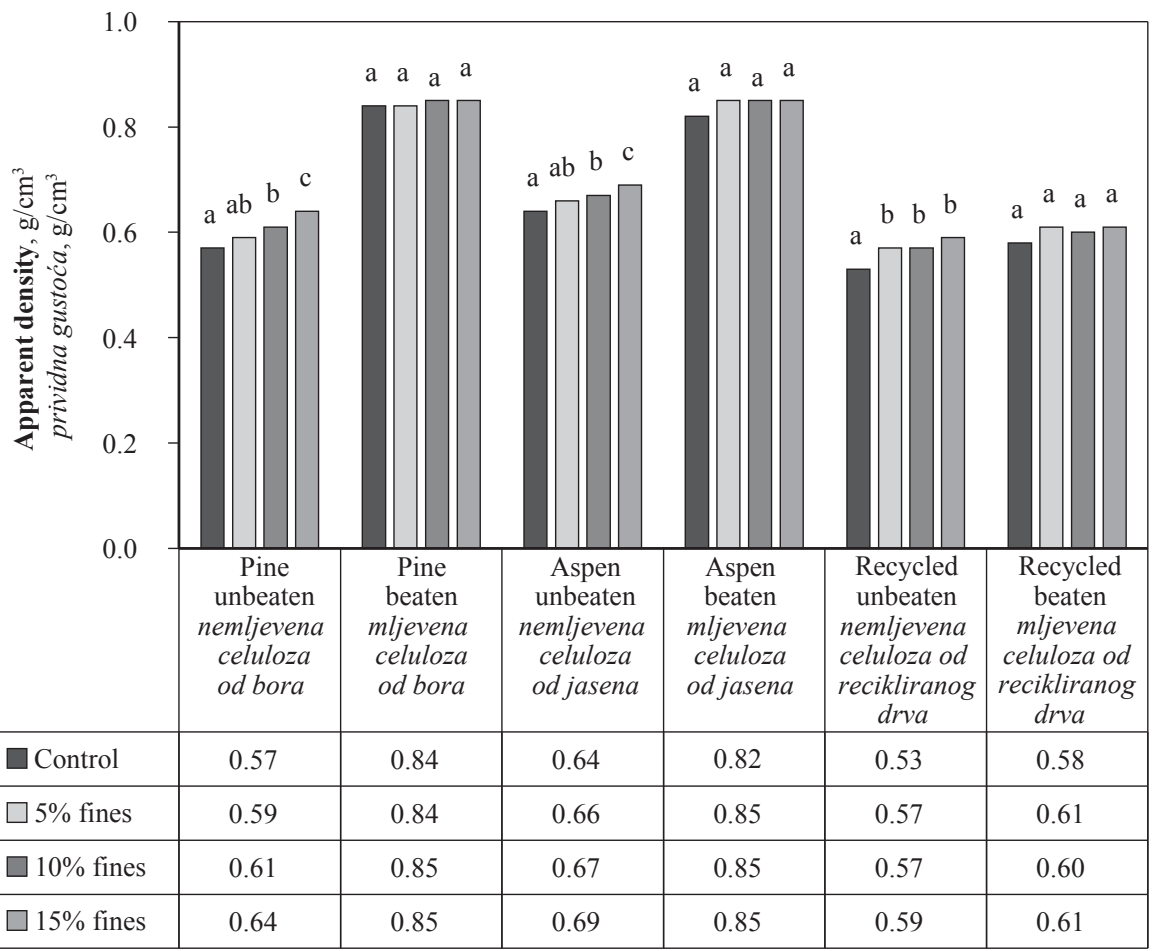

Figure 4 Effect of fines addition on apparent density of hand sheets of unbeaten and beaten pulps

Slika 4. Utjecaj dodatka finih vlakana na prividnu gustoću papira od nemljevene i mljevene celuloze 


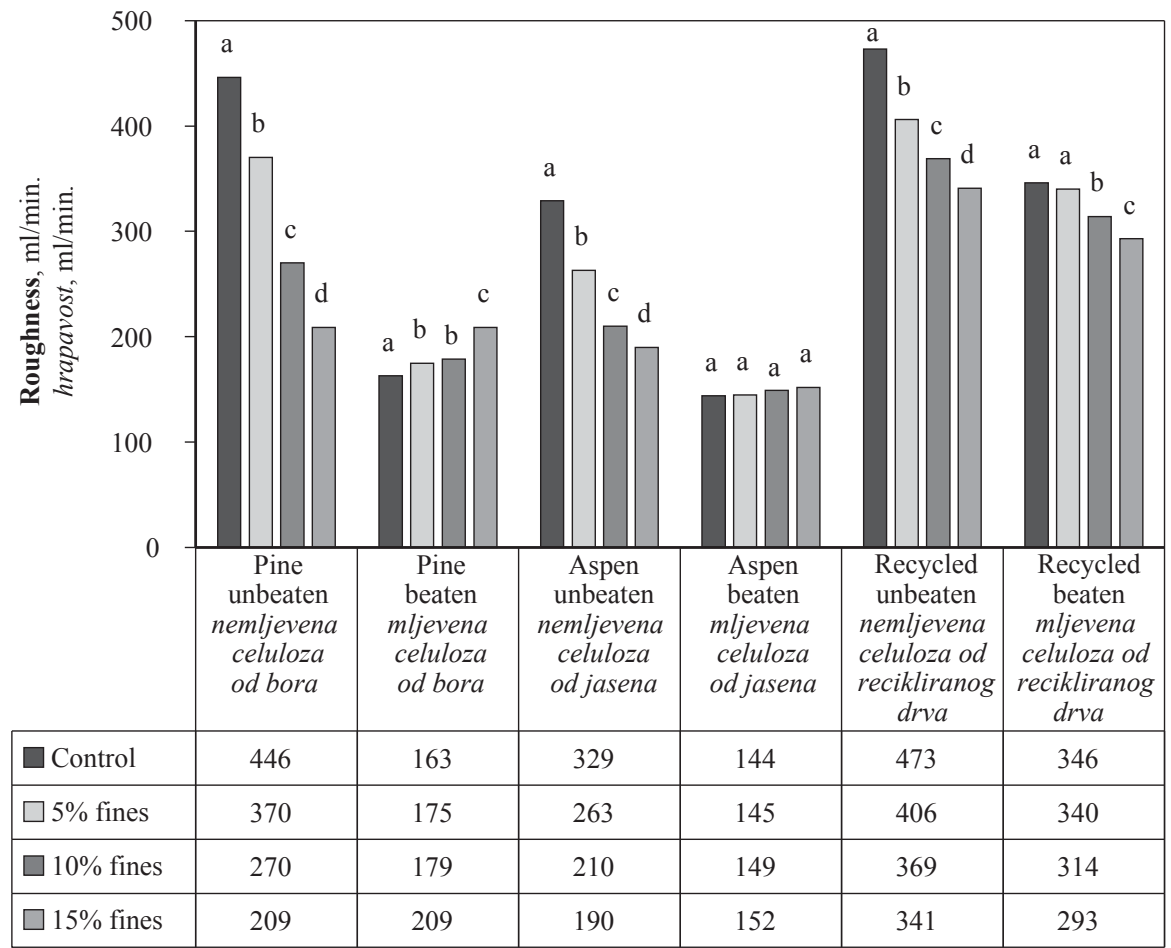

Figure 5 Effect of fines addition on roughness of hand sheets of unbeaten and beaten pulps

Slika 5. Utjecaj dodatka finih vlakana na hrapavost papira od nemljevene i mljevene celuloze

with previous work (Lu 1999), which showed that the sheet density increased with the addition of 20,30 , and $40 \%$ fines to mechanical pulp from $0.372 \mathrm{~g} / \mathrm{cm}^{3}$ to $0.511 \mathrm{~g} / \mathrm{cm}^{3}, 0.555 \mathrm{~g} / \mathrm{cm}^{3}$ and, $0.563 \mathrm{~g} / \mathrm{cm}^{3}$, respectively.

Fines cause an increase in sheet density by filling the voids between the fibers. In addition, Hawes and Doshi (1986) noted that the sheet density increased with the addition of $20 \%$ secondary fines to recycled pulp from $0.549 \mathrm{~g} / \mathrm{cm}^{3}$ to $0.629 \mathrm{~g} / \mathrm{cm}^{3}$. On the other hand, Ferreira et al., (2000) reported that sheet density decreased when fines were removed from fiber suspension from $0.767 \mathrm{~g} / \mathrm{cm}^{3}$ to $0.708 \mathrm{~g} / \mathrm{cm}^{3}$. The positive correlation between fine addition and sheet density has also been reported by other authors (Mohlin, 1977; Hartman, 1984; Hawes and Doshi, 1986; Waterhouse and Omiri, 1993; Lu, 1999; Bäckström et al., 2008; Lee et al., 2011; Moberg et al., 2014).

In beaten pulps of all types of pulp, the addition of fines had a statistically insignificant effect $(p>0.05)$ on apparent density of hand sheets (Figure 4). These results indicated that the freeness level of pulp is more important for the apparent density than the content of fines. For example, apparent density of European aspen kraft pulp was increased with beating up to $28{ }^{\circ} \mathrm{SR}$ from 0.64 $\mathrm{g} / \mathrm{cm}^{3}$ to $0.82 \mathrm{~g} / \mathrm{cm}^{3}$. Whereas, apparent density of European aspen kraft pulp with the addition of $15 \%$ fines was increased from $0.64 \mathrm{~g} / \mathrm{cm}^{3}$ to $0.69 \mathrm{~g} / \mathrm{cm}^{3}$.

\subsection{Roughness}

\subsection{Hrapavost}

Hand sheet roughness was significantly affected by fines. In unbeaten pulps of all types of pulp, roughness of hand sheets decreased with the addition of fines (Figure 5). The effect of fines addition on roughness of
Turkish Calabrian pine hand sheets was more pronounced than that of other pulps. In Turkish Calabrian pine unbeaten kraft pulp, the addition of 5, 10, and $15 \%$ secondary fines resulted in a decrease in roughness of $17.04 \%, 39.46 \%$, and $53.14 \%$, respectively $(p<0.05)$. Roughness decrease in European aspen kraft pulp and recycled pulp was found to be $20.06 \%, 36.17 \%, 42.25$ $\%$ and $14.16 \%, 21.98 \%, 27.90 \%$, respectively $(p<0.05)$. These results can be explained by the fact that fines act as a filler material in the paper structure. Positive effect of fines on surface smoothness was also reported by Waterhouse and Omiri (1993) and Lu (1999).

In beaten pulps of Turkish Calabrian pine kraft pulp, hand sheet roughness increased with the addition of 5,10 , and $15 \%$ secondary fines by $7.36 \%, 9.82 \%$, and $28.22 \%$, respectively $(p<0.05)$. Quite the contrary, the addition of 5,10 , and $15 \%$ fines to recycled beaten pulp resulted in a roughness decrease of $1.73 \%, 9.25$ $\%$, and $15.32 \%$, respectively $(p<0.05)$. The effect of fines on hand sheet roughness of European aspen kraft pulp was statistically insignificant $(p>0.05)$ (Figure 5).

\subsection{Air permeance}

\subsection{Propusnost zraka}

In unbeaten pulps of all types of pulp, air permeance of hand sheets decreased dramatically with increasing addition of fines (Figure 6). In Turkish Calabrian pines samples, the effect of fines on air permeance was more prominent than in other pulps. In Turkish Calabrian pine unbeaten kraft pulp, the addition of 5,10 , and $15 \%$ fines caused an increase in air permeance of $9.24 \%, 47.35 \%$, and $85.11 \%$, respectively $(p<0.05)$. Air permeance of hand sheets of European aspen unbeaten kraft pulp and recycled unbeaten pulp decreased by $31.91 \%, 67.54 \%, 80.20 \%$, and 


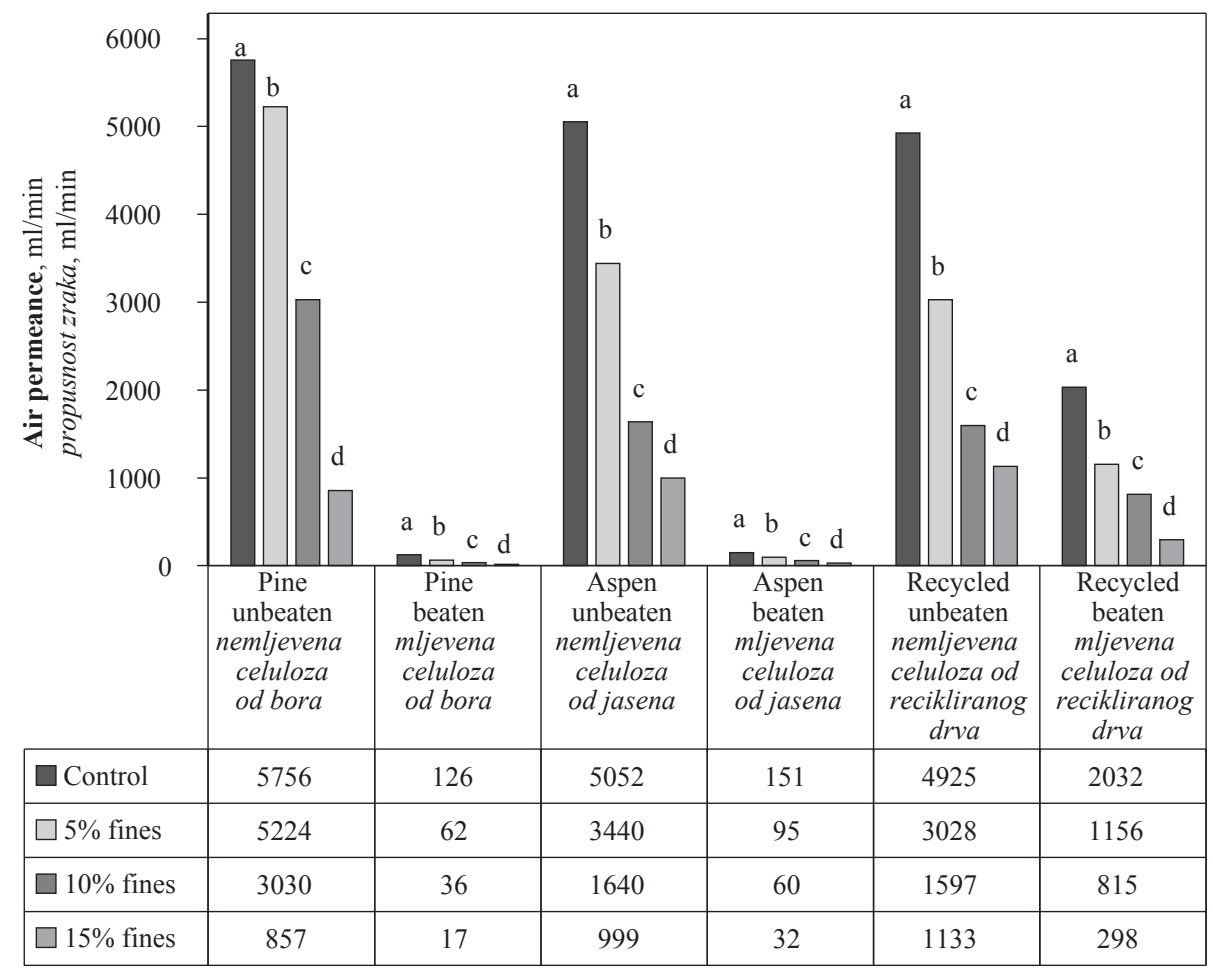

Figure 6 Effect of fines addition on air permeance of hand sheets of unbeaten and beaten pulps

Slika 6. Utjecaj dodatka finih vlakana na propusnost zraka papira od nemljevene i mljevene celuloze

$38.52 \%, 67.57 \%, 76.99 \%$, respectively $(p<0.05)$, with the addition of 5,10 , and $15 \%$ fines. Increasing the amount of fines in furnish also leads to decreased air permeance. Fines cause the decrease in air permeance by filling the voids of the fiber network. In other words, air permeance (Figure 6) tends to decrease with the addition of fines due to better conformity, reduction of spaces between fibers and increase of resistance to air flow (Yasumura et al., 2012). Decreasing air permeance with the addition of fines can also be attributed to increasing apparent density with the addition of fines. At higher apparent densities, the pores in the sheet begin to close up due to better bonding. This led to the decrease in air permeance. Reduced air permeance retards moisture escape and slows the drying rate. Both factors contribute to decreased paper machine productivity (Seth, 2003).

$\mathrm{Lu}$ (1999) reported that air permeance decreased with the addition of 20,30 , and $40 \%$ fines to mechanical pulp from $2538 \mathrm{ml} / \mathrm{min}$. to $922 \mathrm{ml} / \mathrm{min}$., $124 \mathrm{ml} / \mathrm{min}$, and $52 \mathrm{ml} / \mathrm{min}$. respectively. Asikainen et al., (2010) noted that air resistance (Gurley method) increased with the addition of $10 \%$ and $20 \%$ primary fines to CTMP from $2.8 \mathrm{sec}$. to $7.7 \mathrm{sec}$. and $22.2 \mathrm{sec}$, respectively. On the other hand, Ferreira et al., (2000) noted that air permeance decreased when fines were removed from fiber suspension from $54.5 \mathrm{ml} / \mathrm{min}$. to $26 \mathrm{ml} / \mathrm{min}$. Htun and de Ruvo (1978) reported that the removal of fines resulted in increased air permeability. The effect of fines on hand sheet air permeance has also been reported previously (Hartman, 1984; Hawes and Doshi, 1986; Waterhouse and Omiri, 1993; Lu, 1999; Seth, 2003; Hubbe and Heitmann, 2007; Lee et al., 2011).
Regarding unbeaten pulp samples, air permeance of beaten pulps decreased with the addition of fines (Figure 6). There was a linear correlation between fines addition ratio and air permeance of hand sheets. Air permeance of beaten kraft pulps of Turkish Calabrian pine and European aspen decreased by $50.79 \%, 71.43$ $\%, 86.51 \%$, and $37.08 \%, 60.26 \%, 78.80 \%$, respectively $(p<0.05)$ with the addition of 5,10 , and $15 \%$ fines. In the recycled beaten pulps, the addition of 5 , 10 , and $15 \%$ fines caused an decrease in air permeance of $43.11 \%, 59.89 \%$, and $85.33 \%$, respectively $(p<0,05)$. For virgin pulps, the pulp freeness level had a more significant effect on air permeance than the content of fines, and vice versa for recycled pulp. For example, when the $15 \%$ fines were added to Turkish Calabrian pine kraft pulp, hand sheet air permeance decreased from $5756 \mathrm{ml} / \mathrm{min}$. to $857 \mathrm{ml} / \mathrm{min}$. However, hand sheet air permeance was decreased with beating up to $28{ }^{\circ} \mathrm{SR}$ from $5756 \mathrm{ml} / \mathrm{min}$. to $126 \mathrm{ml} / \mathrm{min}$. On the other hand, in the recycled pulp, hand sheet air permeance was decreased with beating up to $28{ }^{\circ} \mathrm{SR}$ from $4925 \mathrm{ml} / \mathrm{min}$. to $2032 \mathrm{ml} / \mathrm{min}$, while hand sheet air permeance was decreased from $4925 \mathrm{ml} / \mathrm{min}$. to $1133 \mathrm{ml} /$ min with the addition of $15 \%$ fines.

\section{CONCLUSIONS}

\section{ZAKLJUČAK}

Unless they are specifically removed, fines are present in any paper and influence its properties. In order to optimize the paper strength, it is important to control the fines content. In this study, the effect of fines on hand sheet properties was determined on dif- 
ferent types of pulp (pine kraft pulp, aspen kraft pulp, and recycled pulp), as well as different pulp freeness levels (unbeaten pulp and $28{ }^{\circ} \mathrm{SR}$ pulp). Based on the results, it can be concluded that secondary fines of recycled pulp have a significant impact on hand sheet properties. The effect of fines on hand sheet properties correlates strongly with the type of pulp, freeness level of pulp, and amount of fines addition. The effect of the addition of fines on hand sheet properties of unbeaten pulps was more prominent than of beaten pulps. On the other hand, effect of fines on hand sheet properties of the unbeaten and beaten pulps was dependent on the type of pulp. In the unbeaten and beaten pulp samples, the effect of fines addition was more pronounced in European aspen kraft pulp and recycled pulp than in Turkish Calabrian pine kraft pulp. The differences in hand sheet properties became more visible with the increasing fines content.

The highest paper strength increase rates were obtained from unbeaten pulps with $15 \%$ fines. Paper strength of $15 \%$ fines added unbeaten recycled pulp was higher than that of fines-free beaten recycled pulp. This demonstrates that it is possible to reduce the beating level by adding fines to recycled pulp. The results suggested that fines can be used as reinforcement for papermaking to improve the paper properties. In the papermaking process, fines can also be used as a potential control variable in order to obtain desirable paper properties. When the beating level and fines addition ratio are determined properly, refining energy requirements can be reduced, and paper strength can be improved.

\section{REFERENCES}

5. LITERATURA

1. Asikainen, S.; Fuhrmann, A.; Ranua, M.; Robertsen, L., 2010: Effect of birch kraft pulp primary fines on bleaching and sheet properties. BioResources, 5 (4): 2173-2183.

2. Bäckström, M.; Kolar, M.-C.; Htun, M., 2008: Characterisation of fines from unbleached kraft pulps and their impact on sheet properties. Holzforschung, 62 (5): 546552. https://doi.org/10.1515/HF.2008.081.

3. Chen, H.; Park, A.; Heitmann, J. A.; Hubbe, M. A., 2009: Importance of cellulosic fines relative to the dewatering rates of fiber suspensions. Industrial \& Engineering Chemistry Research, 48 (20): 9106-9112.

http://doi.org/10.1021/ie9006613.

4. Chen, J.; Zhang, M.; Yuan, Z.; Wang, J., 2013: Improved high-yield pulp network and paper sheet properties by the addition of fines. BioResources, 8 (4): 6309-6322.

5. Ferreira, P. J.; Martins, A. A.; Figueiredo, M. M., 2000: Primary and secondary fines from Eucalyptus globulus kraft pulps. Characterization and influence. Paperi Ja Puu, 82 (6): 403-408.

6. Hartman, R. R., 1984: Mechanical treatment of pulp fibers for property development. Doctoral Thesis. The Institute of Paper Chemistry, Appleton, USA.

7. Hawes, J. M.; Doshi, M. R., 1986: The contribution of different types of fines to the properties of handsheets made from recycled paper. TAPPI Proceedings 1986 Pulping Conference.
8. Htun, M.; de Ruvo, A., 1978: The implication of the fines fraction for properties of bleached kraft sheet. Svensk Papperstidning, 81 (16): 507-510.

9. Hubbe, M. A.; Heitmann, J. A., 2007: Review of factors affecting the release of water from cellulosic fibers during paper manufacture. BioResources, 2 (3): 500-533.

10. Johansson, A., 2008: Correlations between fibre properties and paper properties. Master's Thesis. Helsinki University of Technology.

11. Kibblewhite, R. P., 1972: Effect of beating on fiber morphology and fiber surface structure. Appita, 26 (3): 196-202.

12. Klungness, U. H.; Sanyer, N., 1981: Hardwood pulp utilization: separation of nonfibrous oak components. Tappi, 64 (2): 109-113.

13. Krogerus, B.; Eriksson, L.; Sundberg, A.; Mosbye, J.; Ahlroth, A.; Östlund, I.; Sjöström, L., 2002a: Fines in closed circuits - Final Report. Project No. KCL-P1713-072.

14. Krogerus, B.; Fagerholm, K.; Tikkaja, E., 2002b: Fines from different pulps compared by image analysis. Nordic Pulp and Paper Research, 17 (4): 440-444. https://doi. org/10.3183/npprj-2002-17-04-p440-444.

15. Lee, H.; Nam, W. S.; Sohn, S. D.; Paik, K. H., 2011: Effect of different types of fines on the properties of recycled chemical pulp. Journal of Industrial and Engineering Chemistry, 17 (1): 100-104. https://doi.org/10.1016/j.jiec.2010.12.004.

16. Lin, T.; Yin, X.; Retulainen, E.; Nazhad, M. M., 2007: Effect of chemical pulp fines on filler retention and paper properties. Appita Journal, 60 (6): 469-473.

17. Lindqvist, H.; Salminen, K.; Kataja-aho, J.; Retulainen, E.; Fardim, P.; Sundberg, A., 2011: The effect of fines on dewatering, wet and dry web properties. Paper Conference, Cincinnati, USA.

18. Lindström, T.; Nordmark, G., 1978: Chemical characterization of the fines fraction from unbleached kraft pulps. Svensk Papperstidning, 81 (15): 489-492.

19. Liu, X. A.; Whiting, P.; Pande, H.; Roy, D. N., 2001: The contribution of different fractions of fines to pulp drainage in mechanical pulps. Journal of Pulp and Paper Science, 27 (4): 139-143.

20. Lobben, T. H., 1977: Effect of fines on the paper strength properties of chemical pulps. Norsk Skogindustri, 31 (4): 93-97.

21. Lu, X., 1999: Print mottle of wood-containing paper: the effect of fines and formation. Doctoral Thesis, Graduate Department of Chemical Engineering and Applied Chemistry, University of Toronto.

22. Luukko, K.; Paulapuro, H., 1999: Mechanical pulp fines: Effect of particle size and shape. Tappi Journal, 82 (2): 95-101.

23. Mancebo, R.; Krokoska, P., 1985: The concept, properties and papermaking role of fines. Papir a Celluloza, 36 (11): V71-V81.

24. Meyers, J.; Nanko, H., 2005: Effects of fines on the fiber length and coarseness values measured by the fiber quality analyzer (FQA). TAPPI Practical Papermaking Conference, Milwaukee, WI, USA.

25. Moberg, A.; Goldszer, K.; Ljungqvist, C. H.; Peng, F.; Hafrén, J.; Fernando, D.; Daniel, G., 2014: Mechanical pulping process impact on fines properties and significance for strength density relationships of board centre layers. International Mechanical Pulping Conference, Helsinki, Finland.

26. Mohlin, U. B., 1977: Mechanical pulp properties-the importance of fines retention. Svensk Papperstidning, 80 (3): 84-88. 
27. Moss, P. A.; Retulainen, E., 1997: The effect of fines on fibre bonding: Cross-sectional dimensions of TMP fibres at potential bonding sites. Journal of Pulp and Paper Science, 23 (8): J382-J388.

28. Norell, M.; Johansson, K.; Persson, M., 1999: Retention and drainage. Neimo, L. (ed.). Papermaking Science And Technology, Book 4. Papermaking Chemistry. Fapet Oy, Helsinki.

29. Paradis, M. A.; Genco, J. M.; Bousfield, D. W.; Hassler, J. C.; Wildfong, V., 2002: Determination of drainage resistance coefficients under known shear rate. Tappi Journal, 1 (2): 12-18.

30. Przybysz, K.; Czechowski, J., 1985: The effect of pulp fines on the drying process and paper strength properties. Cellulose Chemistry and Technology, 19 (2): 197-209.

31. Retulainen, E.; Moss, P.; Nieminen, K., 1993: Effect of fines on the properties of fibre networks. Transactions of the $10^{\text {th }}$ Fundamental Research Symposium - Products of Papermaking. Oxford.

32. Retulainen, E., 1997: The role of fibre bonding in paper properties. Doctoral Thesis. Helsinki University of Technology, Espoo, Finland.

33. Retulainen, E.; Luokko, K.; Fagerholm, K.; Pere, J.; Laine, J.; Paulapuro, H., 2002: Papermaking quality of fines from different pulps-the effect of size, shape and chemical composition. Appita Journal, 55 (6): 457-460.

34. Rundlöf, M., 2002: Interaction of dissolved and colloidal substances with fines of mechanical pulp - Influence on sheet properties and basic aspects of adhesion. Doctoral Thesis. TRITA-PMT Report 2002:1.

35. Rushdan, I., 2005: Fines of Acacia mangium recycled kraft paper. Journal of Tropical Forest Science, 17 (3): 325-333.

36. Seth, R. S., 2003: The measurement and significance of fines. Their addition to pulp improves sheet consolidation. Pulp and Paper Canada, 104 (2): 41-44.

37. Silveira, G. G.; Zhang, X.; Berry, R.; Wood, J. R., 1996: Location of fines in mechanical pulp handsheets using scanning electron microscopy. Journal of Pulp and Paper Science, 22 (9): 315-320.

38. Szwarcsztajn, E.; Przybysz, K., 1977: The role of pulp fractions and processing variables in recycling. FibreWater interactions in Papermaking, Oxford, London.
39. Taipale, T., 2010: Interactions of microfibrillated cellulose and cellulosic fines with cationic polyelectrolytes. Doctoral Dissertation. Aalto University School of Science and Technology, Faculty of Chemistry and Materials Sciences, Department of Forest Products Technology, Aalto, Finland.

40. Taipale, T.; Österberg, M.; Nykänen, A.; Ruokolainen, J.; Laine, J., 2010: Effect of microfibrillated cellulose and fines on the drainage of kraft pulp suspension and paper strength. Cellulose, 17 (5): 1005-1020. https://doi.org/10.1007/s10570-010-9431-9.

41. Vainio, A.; Kangas, J.; Paulapuro, H., 2007: The role of TMP fines in interfibre bonding and fibre segment activation. Journal of Pulp and Paper Science, 33 (1): 29-34.

42. Waterhouse, J. F.; Omori, K., 1993: The effect of recycling on the fines contribution to selected paper properties. Transactions of the $10^{\text {th }}$ Fundamental Research Symposium-Products of Papermaking. Oxford.

43. Waterhouse, J. F., 1994: Utilization of recycled fibers. Improved utilization of recycled fines. Institute of Paper Science and Technology, Project F00901, Report 1, Atlanta, Georgia.

44. Yasumura, P. K.; D’Almeida, M. L. O.; Park, S. W., 2012: Multivariate statistical evaluation of physical properties of pulps refined in a pfi mill. O Papel, 73 (3): 59-65.

45. Zaytseva, Y., 2010: Effect of pulps fractionation on formation and strength properties of laboratory handsheets. Master's Thesis, Lappeenranta University of Technology, Faculty of Technology, Department of Chemical Technology, Finland.

\section{Corresponding address:}

\section{SEZGIN KORAY GÜLSOY}

Bartin University, Forestry Faculty

Department of Forest Industry Engineering 74100 Bartin, TURKEY

e-mail: szgngulsoy@yahoo.com 